\title{
What Determines Investment in Renewable Energy?
}

\author{
Evelina Mengova \\ Governors State University
}

Investment in renewable energy is an investment in our future. This paper explores the determinants of investment in renewable energy capacity in Europe, the Former Soviet Union, and the Middle East and North Africa. It explores the major challenges each of these regions faces in moving towards a more environmentally friendly generation and use of energy. We find that specific country and regional characteristics, together with the level of pollution of a country, have a significant impact on its total renewable capacity installed. We find mixed evidence that the overall quality of governance promotes renewables.

Keywords: strategic innovation, sustainability, renewable energy, investment, governance, Europe, Former Soviet Union, Middle East, North Africa

\section{INTRODUCTION}

Investment in renewable energy sources has been an increasingly important component of national policy agendas for many countries over the past decades. One of the reasons has been the growing need for energy for both expanding industrial production, as well as electricity consumption. Conventional sources of energy have been limited, and fast depleting, though. That, combined with the ever-growing awareness of citizens of the negative impact of climate change, has generated also a rising need for a more diverse pool of energy sources, especially for renewable ones.

A longtime leader in many initiatives related to policies and investment in R\&D in renewables has been the European Union. However, in more recent years it has actually been Asia that has had the highest level of investment in renewables, reaching installed capacity of over 1 million MW, which constitutes 44\% of the global total in 2018 (IRENA, 2020). Still, the European Union has produced a plethora of policy initiatives to promote investment and utilization of renewable sources, and comes second in terms of installed renewable capacity, equal to $23 \%$ of the global total in 2018 (IRENA, 2020). This is no small achievement, because renewables can give the European Union member states a competitive, reliable and sustainable energy sector and reduce their dependence on imports of energy. EU countries have been dependent on fossil fuel imports, especially oil and gas, which has created the need to increase the security of their energy needs.

That applies even more strongly to Eastern European and Former Soviet Union countries, which have historically been dependent on energy imports from traditional sources, especially from the Russian Federation. During the socialist period, Russia most of the time was the only exporter of gas and oil to its satellites, often at very low prices, which created a deep reliance of these countries on Russian energy. That tradition carried over to the 1990s and generated not only a strong dependence, but also a lack of 
incentives to look for, and invest in, more diverse sources of energy in the whole region. Many Eastern European countries became EU members over the period 1996-2016, though. As such, they joined the global initiatives of the Kyoto protocol to reduce carbon dioxide emissions, and the specific policies of the EU put in place. EU heads of state have agreed to reduce greenhouse gases emissions $80-95 \%$ below 1990 levels by 2050 (Pacesila et al., 2016).

In addition, according to the 2009/28/EC Directive on the promotion of using energy from renewable sources adopted by the European Parliament and of the Council of Ministers in 2009, the development of renewable energy sources has become one of the main objectives of the EU Energy policy. This directive specifies that the share of renewable energy in total consumption in the EU should reach the target of 20\% by 2020 (European Commission, 2009). All the EU member countries are supposed to set their own national targets for 2020 regarding the share of renewable energy in different sectors of consumption, such as electricity, transportation, heating and cooling, in accordance with that Directive, and then develop national plans on how to reach those goals. Other aspects of the European countries' commitment include exchanging energy from renewable sources among members and cooperating on renewable electricity projects. Furthermore, the EU has in place a monitoring mechanism to observe the progress of each member state: since 1998 Eurobserver barometer has registered the progress of each member state of the EU in the field of renewable energy (Pacesila et al., 2016).

On 30 November 2016, the European Commission published a proposal for a revised Renewable Energy Directive to make the EU a global leader in renewable energy, and ensure that the target of at least $27 \%$ renewables in the final energy consumption in the EU by 2030 was met (European Commission, 2016). In 2018 the European Parliament and Council provisionally agreed to revise this target upward, so that the share of energy from renewables would be at least $32 \%$ of the EU's gross final consumption in 2030 (European Parliament, 2018).

While the progress made by the EU countries towards significant policies related to renewable sources of energy implementation has been no doubt substantial, some major questions remain. Has this EU policy had enough impact on countries in Eastern Europe, which have been only recently accepted in the EU? Have all these policies had enough time to be implemented in practice, so as to produce measurable results in terms of renewable capacity installed? Have all these policies had a spill-over effect over neighboring regions such as the countries of the Former Soviet Union, as well as the countries in the Middle East and North Africa, which have had their specific regional challenges, but also opportunities to invest in renewable energy?

The focus of this paper is to provide an empirical evaluation over the period 2000-2016 of the determinants that affect the installed capacity of renewable energy sources. The countries covered include Europe, both Western and Eastern, as well as its neighboring countries of the Former Soviet Union, together with the Middle East and North Africa region. The paper presents convincing empirical evidence that factors related to country development, such as GDP per capita and renewable energy consumption per capita affect positively the total capacity of renewables installed. Population, as well as pollution, measured by the share of carbon dioxide emissions from gas and liquid fuels also act as incentives to invest more in local renewables. However, energy imports (a proxy for energy dependence), and energy use per capita do not seem to push towards more capacity of cleaner energy installed.

We use regression analysis methodology to determine the relationship among the variables we consider. In our regressions we also control for other possible explanatory variables, such as energy use per capita, carbon dioxide emissions from gas and liquid fuels consumption, total natural resources rents, together with indicators measuring the general quality of institutions and the business environment in a country. The institutional quality indicators include control of corruption, government effectiveness, political stability, regulatory quality, rule of law, and voice and accountability. The data come from the International Renewable Energy Agency (IRENA) and the World Bank's World Development Indicators database, which we use to analyze an unbalanced panel of 66 countries for year 2000, and annual data for the period 2002-2016. 2016 is the last year we have available data for all the country variables included in our sample. 


\section{LITERATURE REVIEW}

The European Union has a prominent role in many climate change related initiatiaves, as well as in the creation of a rich policy framerwork to promote investment in renewable energy, therefore an abundant share of the literature has been dedicated to EU countries and policies. Marques and Fuinhas (2011) analyze the drivers promoting renewable energy, using a dynamic panel approach, and focusing on a set of 24 European countries for the period from 1990 to 2006. Their motivation for the choice of countries is that Europe is a leading player in the fight against climate change, and therefore its renewables market and policies deserve a deeper examination. Rio and Mir-Artigues (2014) review a variety of combinations of support instruments for production of electricity from renewable sources in the EU, using different sources of data. D'Adamo and Rosa (2016) present a research assessment of the European renewable energy sources trajectory towards achieving the 2020 targets. They also propose a new framework to evaluate the performance of EU members, based on three indicators: the share of energy from renewable sources in gross final energy consumption, renewable energy primary production per capita and gross final consumption of renewable energy per capita.

Rio et al. (2017) assess several pathways of a harmonized European policy framework for supporting renewable electricity in a 2030 horizon according to different criteria. They discuss at length the current and future targets for renewable energy both for the EU as a whole, as well as the non-binding national targets for the member states, and the various ways to achieve them. Papież et al. (2018) explore the determinants of renewable energy development in 26 EU countries in the period 1995-2014, using a variety of statistical methods. They discover that the distribution of energy sources in 1995 is crucial in defining the renewable energy development of a country twenty years down the road. Rio and Tarancon (2012) try to identify the determinants of on-shore wind electricity capacity additions in the EU member countries. Their results indicate that capacity additions are significantly and negatively related to administrative barriers and changes in the support scheme, and positively and significantly related to the general investment climate. Biesenbender and Tosun (2014) look at environmentally friendly policy adoptions and policy changes in 24 OECD countries over a period of thirty years (1976-2005). The focus of their research are public policy innovations and their diffusion from one jurisdiction to another, exploring how environmental policies promoted by international organizations changed in different countries after their adoption. Massey et al. (2014) also analyze climate policy innovation, by examining the adoption and diffusion of adaptation policies across 29 European countries in the period 2005-2010, to conclude it is largely driven by internal factors. Schaffer and Bernauer (2014) explore government choices for promoting renewable energy in 26 industrialized countries for the period 1990-2010 and they discover that three main factors play a particularly important role in pushing countries towards marketbased support systems: the characteristics of the existing energy supply system, a federalist structure of the political system, and EU membership. Another important finding in their paper is that higher shares of traditional energy supply and higher $\mathrm{CO}_{2}$ intensity of the economy actually increase the likelihood of a country adopting renewable energy policies, rather than obstructing them.

Some studies do expand the scope of research on renewables, by including also developing countries. Pfeiffer and Mulder (2013) investigate a variety of factors that potentially affect the diffusion of nonhydro renewable energy technology in a large sample of 108 developing countries between 1980 and 2010. They find that renewable energy diffusion accelerates with the implementation of economic and regulatory instruments, higher per capita income and schooling levels, and stable, democratic regimes. At the same time, they argue that increasing openness and aid, institutional and strategic policy support programs, growth of electricity consumption, and high fossil fuel production delay non-hydro renewable energy diffusion. Salim and Rafiq (2012) look at a panel of six emerging economies: Brazil, China, India, Indonesia, Philippines and Turkey, to find that renewable energy adoption in these countries is defined predominantly by income and pollution levels. Stadelmann and Castro (2014) analyze 112 developing and emerging countries from 1998 to 2009, focusing on the "diffusion" rather than "invention" of climaterelevant policies. They explore both domestic and international determinants of renewable energy policies adoption, to discover that countries with larger populations and more wealth exhibit a higher probability 
of adoption of such policies. Among the international factors, they observe that emulation from colonial peers and EU membership facilitate renewable energy policies adoption. Biswas et. al (2012) look at a large sample of 100 countries from 1999 to 2005 and find that control of corruption can limit the pollution generated by the shadow economies of these countries.

Aguirre and Ibikunle (2014) investigate factors affecting country-level renewable energy growth by applying a variety of estimation methods on a global sample of 38 countries during 1990-2010. They pay special attention to Brazil, Russia, India, China and South Africa to reveal new insights. Their results suggest that some government-backed energy policies in fact impede renewable energy investments. They hypothesize that those policies could have been ineffective due to uncertainty and the likelihood of policy discontinuity. Weak voluntary approaches, following global agreements such as the Kyoto Protocol, are also found to be ineffective in promoting renewables growth, compared to mandatory measures. Wang et al. (2018) look at BRICS countries from 1996 to 2015 to find that control of corruption moderates and weakens the relationship between economic growth and $\mathrm{CO}_{2}$ emissions. Lv (2017) argues, though, that democracy reduces $\mathrm{CO}_{2}$ emissions but only if the country has already reached a certain income level, by exploring a sample of 19 emerging countries over the period 1997-2010.

There is relatively less literature dedicated to MENA countries, focused on renewable energy specifically. However, studies on institutional quality, measured by the level of corruption, environmental pollution and GDP growth are more abundant. Goel et al. (2013) find that corruption and the shadow economy (measuring institutional strength) result in higher pollution in MENA countries. Sahli and Rejeb (2015) explore the impact of corruption on pollution and per capita income in 21 countries from the MENA region over the period 1996-2013, with a dynamic panel data model. They find that corruption positively affects per capita emissions of $\mathrm{CO}_{2}$, and negatively affects per capita income. Jebli and Youssef (2015) study the connection between per capita $\mathrm{CO}_{2}$ emissions, GDP, renewable and non-renewable energy consumption and international trade in Tunisia during 1980-2009. Their policy recommendations related to renewable energy for Tunisia are to promote the benefits from renewable energy technology transfers and to encourage renewable energy projects. Kahia et al. (2017) explore the relationship between energy use and economic growth in a sample of net oil importing MENA countries, by separating the effects of renewable and non-renewable energy use on GDP growth, during the period 1980-2012.

Our results build on previous studies and findings. We use the EU countries as a starting point and a benchmark for renewable energy policies and practices, but then we focus also on Eastern Europe and the Former Soviet Union. We add the Middle East and North Africa to our sample of countries, because this region, less researched in the academic literature, has a substantial unexplored potential to invest in renewables in the future.

\section{EMPIRICAL ANALYSIS}

\section{Investment in Renewable Energy - Country Energy Profiles, Environmental and Institutional Quality Indicators}

The data set we use is constructed from databases of IRENA (2019), and the World Bank's World Development Indicators, and contains observations for 66 countries (WDI, 2019). Given the different level of economic development of the countries included in our sample, and the historical differences in the development of their institutional quality, we split the sample into four regional groups. These groups are:

1. Western Europe (West): Austria, Belgium, Cyprus, Denmark, Finland, France, Germany, Greece, Iceland, Ireland, Italy, Luxembourg, Netherlands, Norway, Portugal, Spain, Sweden, Switzerland, United Kingdom.

2. Eastern Europe (East): Albania, Bosnia and Herzegovina, Bulgaria, Croatia, Czech Republic, Hungary, North Macedonia, Montenegro, Poland, Romania, Serbia, Slovak Republic, Slovenia. 
3. Former Soviet Union (FSU): Armenia, Azerbaijan, Belarus, Estonia, Georgia, Kazakhstan, Kyrgyz Republic, Latvia, Lithuania, Moldova, Russian Federation, Tajikistan, Turkmenistan, Ukraine, Uzbekistan.

4. Middle East and North Africa (MENA): Algeria, Bahrain, Egypt, Iran, Iraq, Israel, Jordan, Kuwait, Lebanon, Malta, Morocco, Oman, Qatar, Saudi Arabia, Tunisia, Turkey, United Arab Emirates, Yemen.

The indicators of institutional quality of different countries include categories such as: "Control of Corruption", "Government Effectiveness", "Political Stability and Absence of Violence/Terrorism", "Regulatory Quality", "Rule of Law", and "Voice and Accountability", measured as percentile ranks. We have an unbalanced panel for the years 2000, and annual data for the period 2002-2016.

Table 1 includes some interesting comparisons of GDP per capita in these four different regions in 2000 and 2016. Even in 2000 the regional differences in income levels between the West and the other groups are substantial, and they remain substantial in 2016. Notably, the MENA region has been and remains wealthier compared to both Eastern European and the Former Soviet Union countries, which in theory shows financial ability to potentially invest in renewable energy capacity. Our paper explores whether that financial and environmental potential has been fulfilled.

TABLE 1 REGIONS BY GDP/CAPITA

\begin{tabular}{|llllr|}
\hline Year / Region & West & East & FSU & \multicolumn{1}{c|}{ MENA } \\
\hline 2000 (current USD) & $25,669.62$ & $3,360.19$ & $1,305.07$ & $9,713.56$ \\
2000 (constant 2010 USD) & $44,233.60$ & $7,227.90$ & $3,286.06$ & $16,879.95$ \\
& & & & \\
2016 (current USD) & $47,096.44$ & $10,103.95$ & $6,271.96$ & $16,248.98$ \\
2016 (constant 2010 USD) & $51,202.90$ & $11,503.34$ & $7,112.05$ & $17,552.86$ \\
\hline
\end{tabular}

Source: The World Bank, WDI (2019).

Figures 1-8 below present the total renewable energy installed (measured as average/year electricity capacity in MW) and the investment in renewable energy (average/year in MW).

Figures 1 and 2 indicate that Western Europe has the highest level of total renewable energy of all the regions we explore: starting at 9,148 MW in 2000 and reaching 22,976 MW in 2016. The region also has the largest investment in renewable sources, with a peak in 2011 and 2012. A lot of this success could be attributed to the concerted effort among the EU countries (and their closest allies) to have clear policies regarding the investment in, and the encouragement of, energy production from renewable sources. Another reason likely is the wealth and stage of development of these countries, so they could generously invest in renewable sources. They not only have the policies, but also the funds needed to put those policies in practice: in 2015 alone Europe invested USD 63 billion in renewable energy, with a culmination of new investment of USD 128 billion in 2011 (IRENA, 2019). 
FIGURE 1

WESTERN EUROPE: TOTAL RENEWABLE ENERGY

(AVERAGE ELECTRICITY CAPACITY, MW)

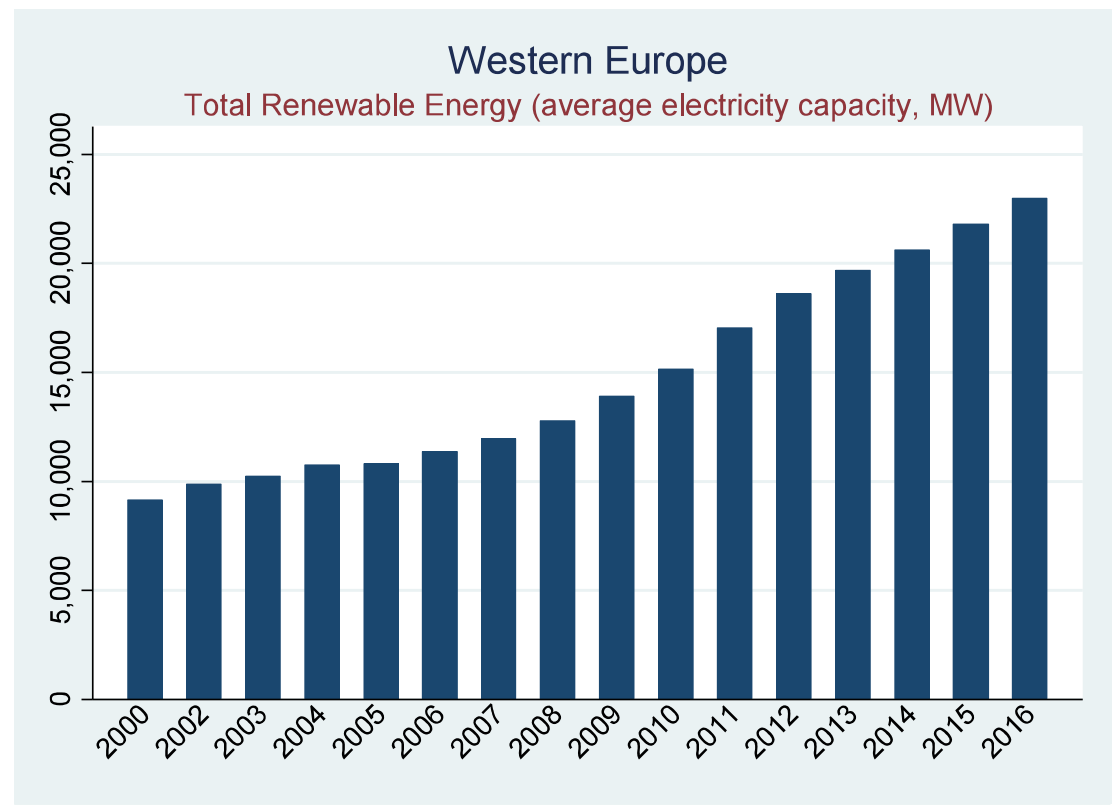

Source: IRENA (2019).

FIGURE 2

WESTERN EUROPE: RENEWABLE ENERGY INVESTMENT (AVERAGE, MW)

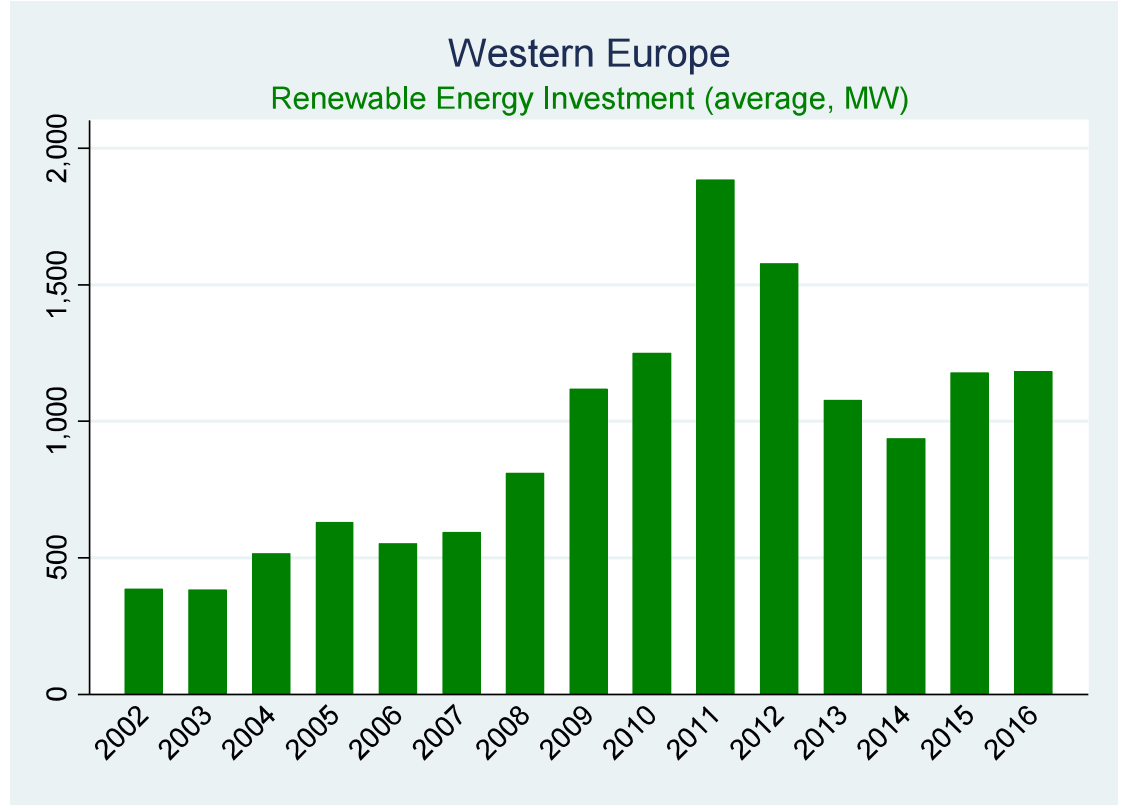

Source: IRENA (2019).

Figures 3 and 4 illustrate that Eastern Europe has made a significant improvement in its total renewable energy capacity: starting at 1,641 MW in 2000, it reaches 3,283 MW in 2016. Eastern Europe 
has invested considerably in renewable sources after 2010, with the highest levels in 2012 and 2013. A lot of this success is likely driven by the accession of several of these countries into the EU, which provided well-defined policies and rules regarding clean energy production, as well as cohesion funds transferred to Eastern Europe, so that the region can improve its energy profile.

\section{FIGURE 3}

\section{EASTERN EUROPE: TOTAL RENEWABLE ENERGY} (AVERAGE ELECTRICITY CAPACITY, MW)

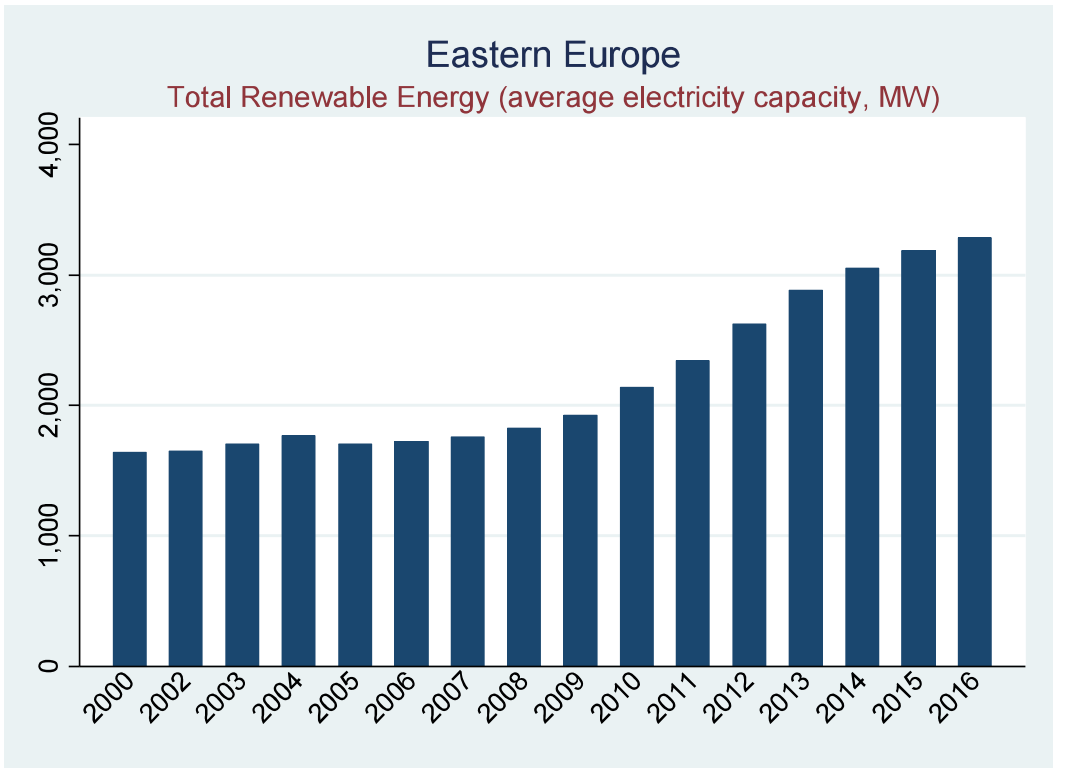

Source: IRENA (2019).

FIGURE 4

EASTERN EUROPE: RENEWABLE ENERGY INVESTMENT (AVERAGE, MW)

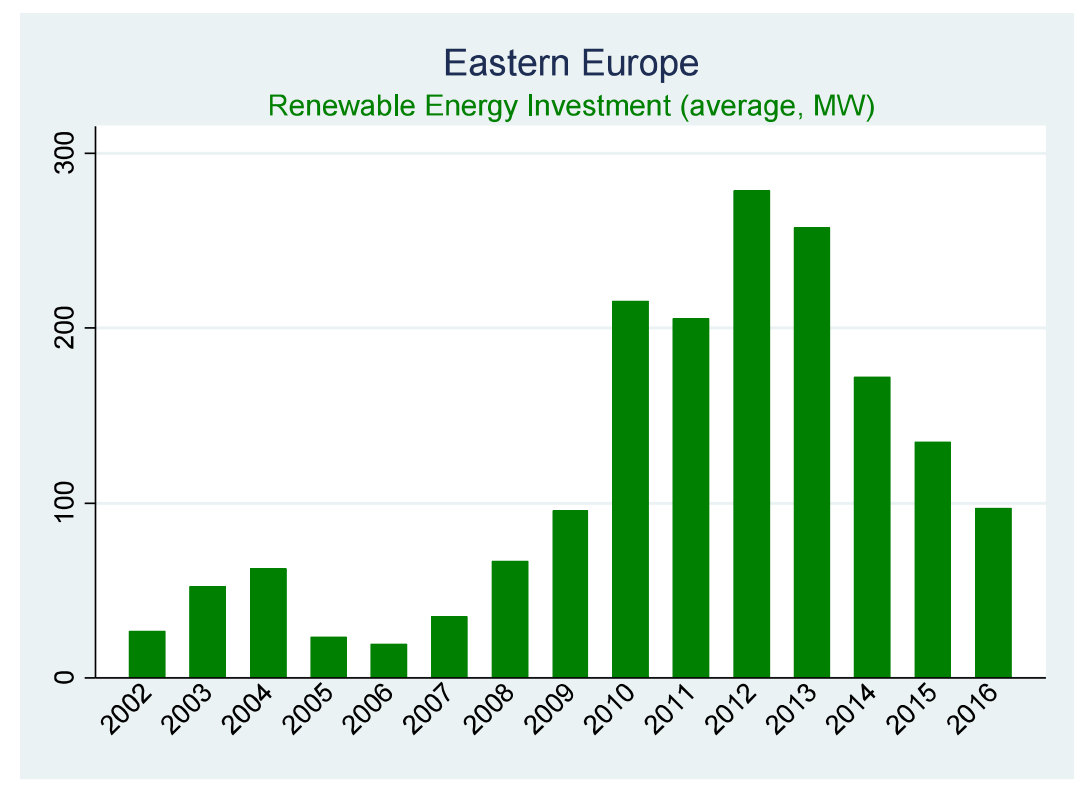

Source: IRENA (2019). 
Figures 5 and 6 show that the Former Soviet Union countries start at a pretty high level of 4,408 MW in 2000 to reach 5,288 MW in 2016, which is mostly due to hydro power. This is still an impressive accomplishment, given that the region is not particularly wealthy, neither it has the policies, nor the investment funds generously provided by the EU, to improve their energy profile. In terms of investment in renewable sources, they have not added that much new capacity in the period $2000-2011$ but have experienced a noticeable increase in added renewables in 2012 and 2013.

\section{FIGURE 5}

\section{FORMER SOVIET UNION: TOTAL RENEWABLE ENERGY (AVERAGE ELECTRICITY CAPACITY, MW)}

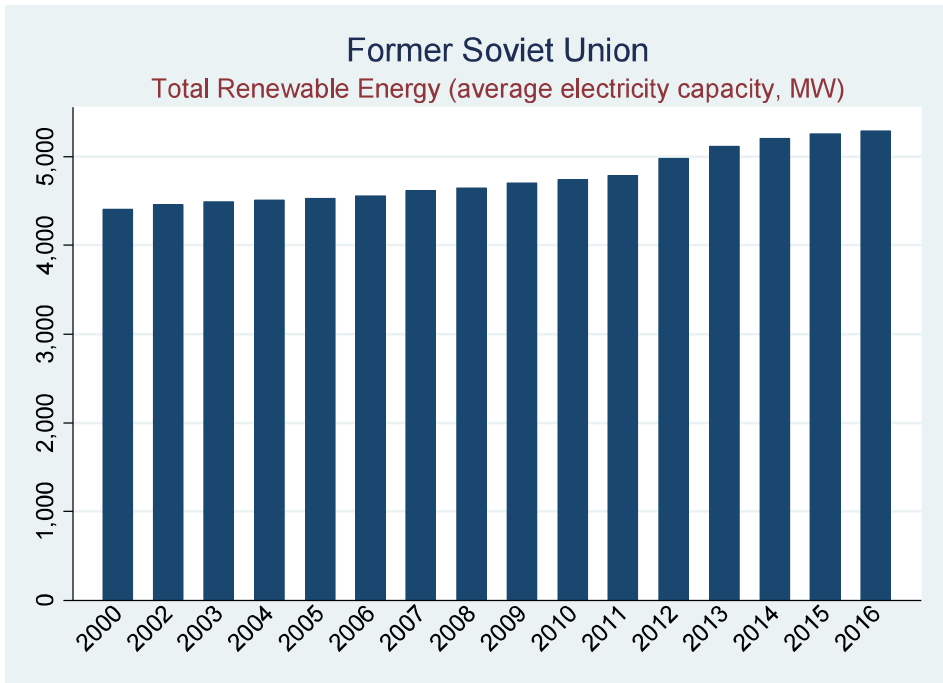

Source: IRENA (2019)

FIGURE 6

FORMER SOVIET UNION: RENEWABLE ENERGY INVESTMENT (AVERAGE, MW)

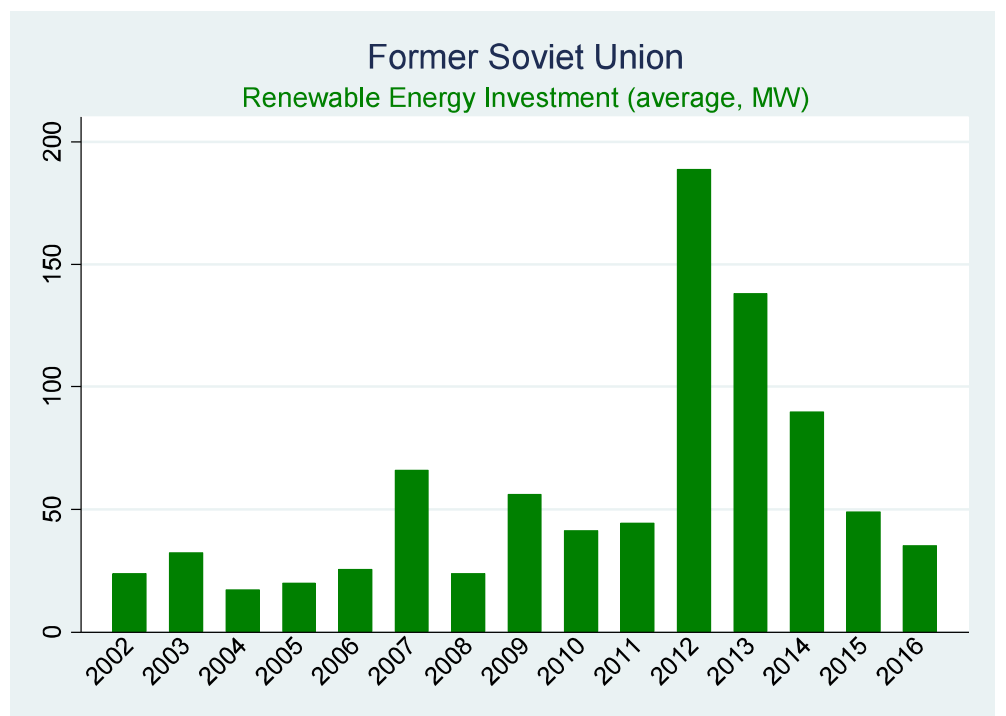

Source: IRENA (2019). 
The Middle East and North Africa region, quite a bit wealthier than the countries in both Eastern Europe and the FSU (as could be observed in Table 1), and therefore having the financial capability to improve its energy efficiency overall, starts at 1,707 MW in 2000 and reaches 3,210 MW in 2016 (Figure 7) - levels comparable to those in Eastern Europe. The region exhibits a steady increase in investment in renewable capacity during the whole period of this research: 2002 to 2016, however - with a noticeable expansion after 2012 (Figure 8). This is commendable, in view of the vast potential of these countries to invest in solar and wind energy, for example. This positive development is expected to continue in the future, according to the newest report by the International Renewable Energy Agency on the countries of the Gulf Cooperation Council (GCC) ${ }^{1}$, IRENA (2019).

\section{FIGURE 7}

\section{MIDDLE EAST AND NORTH AFRICA: TOTAL RENEWABLE ENERGY (AVERAGE ELECTRICITY CAPACITY, MW)}

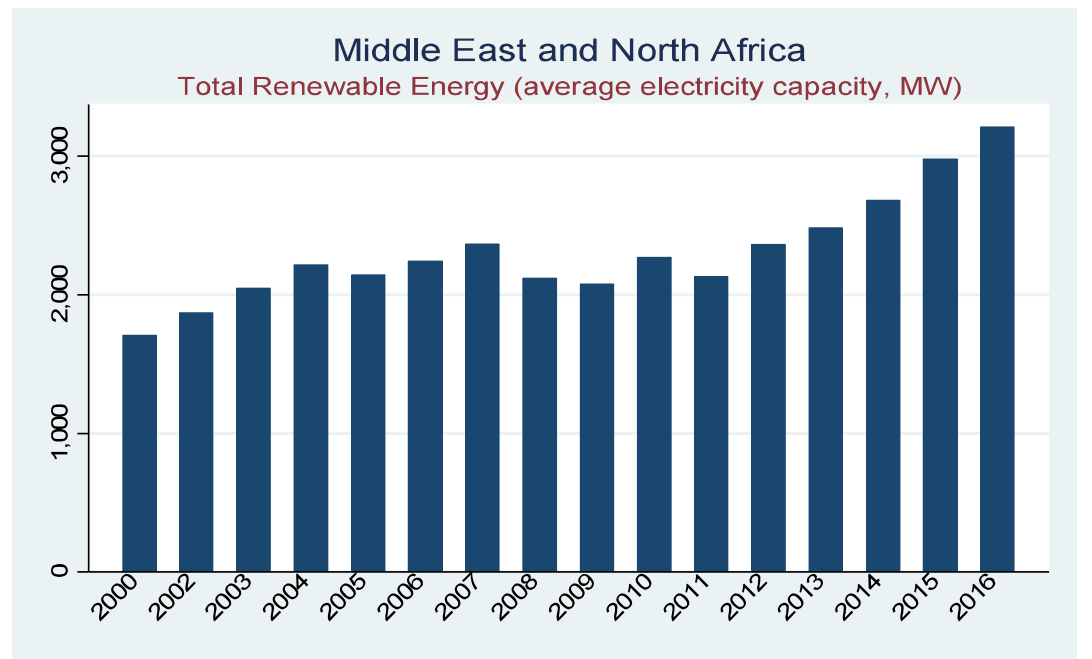

Source: IRENA (2019).

\section{FIGURE 8 \\ MIDDLE EAST AND NORTH AFRICA: RENEWABLE ENERGY INVESTMENT (AVERAGE, MW)}

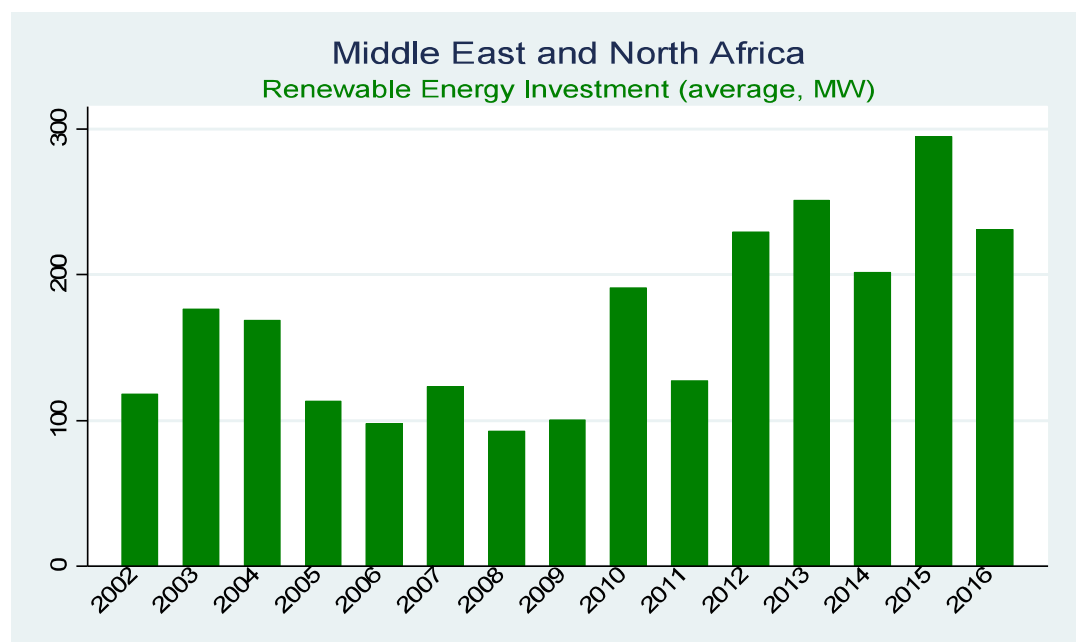

Source: IRENA (2019) 


\section{Models and Estimation}

The main model estimated in this paper analyzes the determinants of investment in renewable energy, assessed by the installed capacity of renewable sources in different countries. Our dependent variable is (Total Renewable Energy) $i$, measured by the electricity capacity in mega watts (MW) in country $i$ and year $j$. The detailed descriptions of all the variables used, as well as their summary statistics, are presented in Tables A1 and A2 in the Appendix. We also include the following country-specific indicators:

$(\text { Total Renewable Energy })_{i j}=\beta_{0}+\beta_{1} *(\text { RE Consumption })_{i j}+\beta_{2} *($ Energy Imports $)+\beta_{3} *($ Energy Use $)+$ $\beta_{4} *(\text { Country Performance Indicators })_{i j}+\beta_{5} *(\text { Total Natural Resources rents })_{i j}+\beta_{6} *\left(\mathrm{CO}_{2}\right.$ Emissions from Electricity Production $)_{i j}+\beta_{7} *(\text { Institutional Indicators })_{i j}+\beta_{8} *(\text { Regional Dummies })_{i j}+\varepsilon_{i j}$,

where:

- $\boldsymbol{R E}$ Consumption measures renewable energy consumption as a percentage of total final energy consumption in a country. The hypothesis tested here is that higher consumption of renewable energy will promote higher investment in renewable sources in general, so we anticipate a strong positive relationship between the two, and a statistically significant positive coefficient.

- Energy Imports is a proxy for import dependence, and as such reflects the energy security of a country. Energy dependence is considered to be a crucial policy issue for both developed EU countries, and transitional and developing countries in our sample. Theoretically the assumption is, that the higher the reliance of a country on energy imports, the higher the level of renewables investment required to ensure that country's energy security. In other words, one would expect a significant positive coefficient.

- Energy Use per capita measures how much actual energy a country consumes in $\mathrm{kg}$ of oil equivalent per capita. A reasonable hypothesis is that the higher the energy use of a country, the more it may be willing to invest in any energy-producing capacity, including renewable capacity. However, a developing economy with increasing energy needs may also choose to generate the necessary energy from other, nongreen sources as well. It is not clear, therefore, which factor may prevail.

- Country Performance Indicators include GDP per capita and population. We expect a clear positive relationship between both higher GDP per capita, indicating a higher level of income and thus ability to invest in and promote renewable energy and a larger population, stimulating more energy production from renewables.

- Total Natural Resources rents as percentage of GDP is a proxy of how a country chooses to utilize its natural resources. Total natural resources rents are the sum of oil rents, natural gas rents, coal rents (hard and soft), mineral rents, and forest rents. "Rents" are the difference between the value of production at world prices and the total costs of production. Therefore, the higher the "rents" extracted from natural resources for different purposes, the lower the expected investment specifically in renewable energy in any given country.

- $\mathrm{CO}_{2}$ Emissions from Electricity Production accounts for $\mathrm{CO}_{2}$ emissions generated both from gaseous and from liquid fuel consumption. This is a good indicator of the environmental quality of a country, and therefore of the existing incentives to develop cleaner sources of energy. Given the huge significance of $\mathrm{CO}_{2}$ emissions in climate change, environmental concerns in general should have a positive impact on renewables investment.

- Institutional Indicators include control of corruption, government effectiveness, regulatory quality, political stability, rule of law, and voice and accountability. Theories of institutional quality state that the characteristics of a political system influence both the policy adoption, and the general business climate in a given country. The literature on the role of democracy in environmental protection is quite rich. Congleton (1992) presents a theory that authoritarian regimes would adopt less stringent environmental standards than democratic ones, since democratic governments tend to follow the preferences of the median voter, who benefits more from the public provision of environmental quality than the authoritarian ruler. That theory is also explored by Fredriksson (1997) and Deacon (2000). A study of former communist countries questions this link between democracy and environmentally conscious policies (Midlarsky, 1998), by presenting evidence that the statistically significant effect of democracy on 
the environment is actually negative, contrary to previous theoretical predictions. That paper encourages re-examining of one-dimensional theoretical assumptions and policies concerning the positive effect of democracy on the environment. Other studies, such as those by Fredriksson and Gaston (2000), Neumayer (2002), and Li and Reuveny (2006), show that stronger democracies usually exhibit stronger environmental commitment than weaker ones. However, Neumayer (2002) indicates that the strong evidence in favor of a positive link between democracy and environmental commitment is in contrast with the somewhat weak evidence on such a link between democracy and environmental outcomes themselves. Therefore, our initial theoretical hypothesis is that the more democratic the governance of a country is, the more likely it is to adopt policies that support renewable energy advancement and to create a business environment more prone to investing in renewables. But we also recognize that the adoption of environmental policies by itself does not always translate into a more effective deployment of renewable sources.

- Regional dummy variables include dummies for Eastern Europe, the Former Soviet Union and the Middle East and North Africa, as three separate regions, as well as for the EU as a whole. The baseline is the energy performance of Western Europe, so the other three dummies capture whether a given region performs better, or worse, compared to Western Europe in terms of installed capacity of renewable energy.

\section{Estimation Results}

The results are presented in Table 2 below. As one can observe, most of the variables perform as expected. To begin with, the higher the share of renewable energy consumption in a country, the more incentives there are to install new renewable energy producing sources. The coefficient of RE share is highly statistically significant and positive in all specifications.

The coeficient of energy imports, i.e. the variable accounting for energy security of a country, turns out to be negative and significant in all specifications. The theoretical assumption that the higher the reliance of a country on energy imports, the higher the level of renewables investment required to ensure that country's energy security is not empirically confirmed in this study. That means that the countries included in our sample might still be inclined to rely on and use more traditional sources of energy to support their growing economies.

The energy use per capita coefficient is significant, albeit slightly negative and small. This also confirms the above-mentioned result that many of the transitional and developing economies included in our study with increasing energy needs may still choose to generate the necessary energy predominantly from other, non-green sources.

The GDP per capita coefficient estimate is small, but positive and significant in all specifications, suggesting that overall the more developed and the wealthier a country is, the more prone and able it is to invest in renewables. Population - another driver of higher energy needs, and therefore a factor promoting higher energy production from all possible souces, including renewables, is positive, and significant in all specifications.

Our hypothesis that given the huge significance of $\mathrm{CO}_{2}$ emissions in climate change, environmental concerns would have a positive impact on renewables investment is confirmed: the $\mathrm{CO}_{2}$ emissions from both gas and liquid fuels proves to be statistically significant and positive in most model specifications. That suggests that in most countries, higher pollution from gaseous and liquid fuels consumption creates social discontent, and therefore political incentives to promote renewable sources of energy.

The indicators we include, accounting for the general institutional quality of a country produce interesting mixed empirical results. Most institutional theories suggest that the characteristics of a political system would influence policy adoption. In other words - the more democtratic and evolved the country is, the more likely it is to promote policies related to the abatement of industrial practices having a negative impact on climate change. Therefore the more prone a country would be to promote investment in renewable sources. In our study, regulatory quality and voice and accountability corroborate this hyposthesis - they are positive and statistically significant. Control of corruption has a negative, and slightly statistically significant coefficient, suggesting that this is not a very informative institutional 
indicator for renewable energy promotion. At the same time, government effectiveness, political stability and the rule of law are not statistically significant. It is worthy to note here, that these indicators are products of survey data, reflecting perceptions of policies. But these policies might not have a significant impact on the actual industrial and business practices in those countries over the period covered in our research. This is also not to say that those policies will not produce positive results in the future, as most of the countries we explore become more democratic, develop better institutions, and their populations start demanding effective establishment of cleaner sources of energy over time.

The regional dummy variables highlight some very interesting results. The baseline is the renewable energy performance of Western Europe, so the other three regional dummies capture, in essence, how much worse does a given region perform, compared to Western Europe. Eastern Europe, for example, has negative coefficients in both specifications, and they are statistically significant. This result suggests that Eastern Europe still has a long way to go to catch up with the renewable capacities installed in the West. So far, the countries in this region have adopted a lot of policies intended to promote investment in clean sources, and the countries who became members of the EU during the period 2000 to 2016 have taken on a variety of commitments to invest in renewables. But these commitments may still be predominantly at a policy level, and still need to produce more tangible results in the future.

The Former Soviet Union dummy has a lower coefficient compared to the Eastern Europe dummy, which is also negative and marginally statistically significant in only one specification. This result confirms what we also see comparing Figure 3 and Figure 5 - that the countries in the FSU actually have a larger installed capacity of renewable sources during the whole period 2000 to 2016, mostly due to previously existing hydro power installations in several of them. Eastern European countries have seen a surge in renewable capacity investment after 2010, and that new investment is higher than the one in the FSU per year, but the average total capacity in the FSU is still larger than in Eastern Europe in 2016.

The MENA region shows significant and negative dummy coefficients, the highest of all three regions, in all specifications. The meaning of this result is that the countries in this region are less likely than Western Europe to invest in, and promote the development of renewable energy, although on average they are wealthier than both the Eastern European, and the Former Soviet Union countries, and in theory at least have the financial capability needed to invest in renewables. They also have the appropriate climate conditions to invest heavily in solar energy, yet very few of them have moved in that direction somewhat sporadically, and only in more recent years. Still, it must be noted that the region has increased the level of new installations of renewable sources after 2010. The development of the renewable energy sector in the Middle East and North Africa is still a project of the future in 2016.

TABLE 2

DEPENDENT VARIABLE: TOTAL RENEWABLE ENERGY (ELECTRICTY CAPACITY, MW)

\begin{tabular}{|l|l|l|l|l|}
\hline & $(1)$ & $(2)$ & $(3)$ & $(4)$ \\
\hline Renewable Energy consumption & $178.4^{* * *}$ & $162.5^{* * *}$ & $228.3^{* * *}$ & $207.5^{* * *}$ \\
\hline $\begin{array}{l}\text { (\% of total final energy } \\
\text { consumption) }\end{array}$ & $(20.17)$ & $(19.84)$ & $(18.65)$ & $(18.92)$ \\
\hline Energy imports & $-10.76^{* * *}$ & $-11.51^{* * *}$ & $-6.484^{*}$ & $-8.123^{* *}$ \\
\hline & $(2.791)$ & $(2.799)$ & $(2.704)$ & $(2.722)$ \\
\hline Energy use (per capita) & $-0.579^{* * *}$ & $-0.538^{* * *}$ & $-0.529^{* * *}$ & $-0.475^{* *}$ \\
\hline GDP per capita & $(0.125)$ & $(0.128)$ & $(0.133)$ & $(0.139)$ \\
\hline & $0.110^{* * *}$ & $0.117^{* * *}$ & $0.159^{* * *}$ & $0.140^{* * *}$ \\
\hline Population & $(0.0242)$ & $(0.0246)$ & $(0.0202)$ & $(0.0203)$ \\
\hline & $0.000233^{* * *}$ & $0.000228^{* * *}$ & $0.000224^{* * *}$ & $0.000211^{* * *}$ \\
\hline & $(0.0000176)$ & $(0.0000180)$ & $(0.0000178)$ & $(0.0000178)$ \\
\hline
\end{tabular}




\begin{tabular}{|c|c|c|c|c|}
\hline Total natural resources rents & $-77.13^{*}$ & $-95.05^{*}$ & $-86.69^{*}$ & $-99.50^{* *}$ \\
\hline$(\%$ of GDP) & $(37.43)$ & $(37.24)$ & $(37.70)$ & $(37.33)$ \\
\hline \multirow[t]{2}{*}{$\mathrm{CO}_{2}$ emissions from gas } & 14.58 & 4.473 & $36.10^{* *}$ & $40.78^{* *}$ \\
\hline & $(15.52)$ & $(16.46)$ & $(13.22)$ & $(14.33)$ \\
\hline \multirow[t]{2}{*}{$\mathrm{CO}_{2}$ emissions from liquid fuel } & $0.0351^{* * *}$ & $0.0353^{* * *}$ & $0.0406^{* * *}$ & $0.0430^{* * *}$ \\
\hline & $(0.00606)$ & $(0.00621)$ & $(0.00608)$ & $(0.00608)$ \\
\hline \multirow[t]{2}{*}{ Control of corruption (rank) } & $-59.82^{*}$ & & $-83.61^{* *}$ & \\
\hline & $(29.91)$ & & $(28.80)$ & \\
\hline \multirow[t]{2}{*}{ Government effectiveness (rank) } & -2.110 & & -31.73 & \\
\hline & $(38.62)$ & & $(38.53)$ & \\
\hline \multirow[t]{2}{*}{ Regulatory quality (rank) } & $82.33^{* *}$ & & $100.1^{* * *}$ & \\
\hline & $(29.75)$ & & $(29.34)$ & \\
\hline \multirow[t]{2}{*}{ Political stability (rank) } & & -21.35 & & -4.817 \\
\hline & & $(17.20)$ & & $(16.60)$ \\
\hline \multirow[t]{2}{*}{ Rule of law (rank) } & & 13.96 & & $-76.65^{* * *}$ \\
\hline & & $(27.98)$ & & $(21.68)$ \\
\hline \multirow[t]{2}{*}{ Voice and accountability (rank) } & & 11.33 & & $70.00^{* *}$ \\
\hline & & $(26.64)$ & & $(22.92)$ \\
\hline \multirow[t]{2}{*}{ EU (dummy) } & & & $2854.8^{* * *}$ & $2521.0^{* *}$ \\
\hline & & & $(797.0)$ & $(949.8)$ \\
\hline \multirow[t]{2}{*}{ Eastern Europe (dummy) } & $-3310.4^{* *}$ & $-2606.8^{*}$ & & \\
\hline & $(1046.7)$ & $(1055.0)$ & & \\
\hline \multirow[t]{2}{*}{ Former Soviet Union (dummy) } & $-2516.1^{*}$ & -1380.7 & & \\
\hline & $(1250.8)$ & $(1225.4)$ & & \\
\hline \multirow[t]{2}{*}{$\begin{array}{l}\text { Middle East \& North Africa } \\
\text { (dummy) }\end{array}$} & $-6326.4^{* * *}$ & $-6527.1^{* * *}$ & & \\
\hline & $(1056.7)$ & $(1299.4)$ & & \\
\hline$N$ & 834 & 833 & 834 & 833 \\
\hline$R^{2}$ & 0.680 & 0.676 & 0.668 & 0.666 \\
\hline
\end{tabular}

\section{CONCLUSION}

Investment in renewable energy is an investment in our future. This paper explores the determinants of investment in renewable capacity in Europe, the Former Soviet Union, and the Middle East and North Africa. It analyzes the major constraints each of these regions faces in moving towards a more environmentally friendly generation and use of energy. The paper looks for evidence whether country performance indicators (GDP per capita and population), environmental indicators $\left(\mathrm{CO}_{2}\right.$ emissions from gas and liquid fuels), together with quality of governance indicators (control of corruption, government effectiveness, regulatory quality, political stability and absence of violence/terrorism, rule of law, and voice and accountability) and the current energy profile of a country (renewable energy consumption, energy imports, energy use per capita, and total natural resources rents) have an impact on investment in clean energy.

We find that specific country and regional characteristics, together with the overall energy profile of a country, have a significant effect on its total renewable capacity installed. We find mixed evidence that the overall quality of governance promotes renewable energy investment. Western Europe has historically always been and remains a leader in both policy implementation and active investment in, and promotion 
of, renewable sources. The countries in Eastern Europe which became EU members especially, exhibit the biggest improvement in renewable policies adoption, register a visible increase in renewable energy investment after 2010, but still need to make a more tangible progress towards renewables policy implementation and use of EU funds. The Former Soviet Union region has a good start in terms of installed renewable energy capacity even in 2000 but has shown only modest progress in terms of new added capacity by 2016. The Middle East and North Africa region has always had a strong potential and substantial wealth to invest in clean energy, but by 2016 this has remained predominantly an unfulfilled potential.

\section{ENDNOTE}

1. GCC countries include Bahrain, Kuwait, Oman, Qatar, Saudi Arabia, and the United Arab Emirates.

\section{REFERENCES}

Aguirre, M., \& Ibikunle, G. (2014). Determinants of Renewable Energy Growth: A Global Sample Analysis. Energy Policy, 69, 374-384.

Aguirre, M., \& Ibikunle, G. (2014). Determinants of Renewable Energy Growth: A Global Sample Analysis. Energy Policy, 69, 374-384.

Biesenbender, S., \& Tosun, J. (2014). Domestic Politics and the Diffusion of International Policy Innovations: How Does Accommodation Happen? Global Environmental Change, 29, 424-433.

Biswas, A.K., Farzanegan, M.R., \& Thum, M. (2012). Pollution, Shadow Economy and Corruption: Theory and Evidence. Ecological Economics, 75, 114-125.

Congleton, R.D. (1992). Political Institutions and Pollution Control. The Review of Economics and Statistics, 74, 412-421.

D’Adamo, I., \& Rosa, P. (2016). Current State of Renewable Energies Performances in the European Union: A New Reference Framework. Energy Conversion and Management, 121, 84-92.

Deacon, R.T. (2000). The Political Economy of Environment-Development Relationships: A Preliminary Framework. FEEM Nota di Lavoro. Fondazione Eni Enrico Mattei, Milano.

European Commission. (2009). Directive 2009/28/EC of the European Parliament and of the Council of 23 April 2009 on the promotion of the use of energy from renewable sources and amending and subsequently repealing Directives 2001/77/EC and 2003/30/EC.

European Commission. (2016). Revised Renewable Energy Directive. Retrieved from https://ec.europa.eu/energy/en/topics/renewable-energy/renewable-energy-directive

European Parliament. (2018). Energy: new target of 32\% from renewables by 2030 agreed by MEPs and ministers. Retrieved from http://www.europarl.europa.eu/news/en/press-

room/20180614IPR05810/energy-new-target-of-32-from-renewables-by-2030-agreed-by-mepsand-ministers

Fredriksson, P.G. (1997). The Political Economy of Pollution Taxes in a Small Open Economy. Journal of Environmental Economics and Management, 33, 44-58.

Fredriksson, P.G., \& Gaston, N. (2000). Ratification of the 1992 Climate Change Convention: What Determines Legislative Delay? Public Choice, 104, 345-368.

Goel, R., Herrala, R., \& Mazhar, U. (2013). Institutional Quality and Environmental Pollution: MENA Countries versus the Rest of the World. Economic Systems, 37, 508-521.

IRENA. (2019). International Renewable Energy Agency database. Retrieved from http://resourceirena.irena.or $9999 \mathrm{~g} /$ gateway/dashboard/

IRENA. (2019). Renewable Energy Market Analysis: GCC 2019. IRENA, Abu Dhabi.

Jebli, M.B., \& Youssef, S.B. (2015). The Environmental Kuznets Curve, Economic Growth, Renewable and Non-Renewable Energy, and Trade in Tunisia. Renewable and Sustainable Energy Reviews, $47,173-185$. 
Kahia, M., Aissa, M.S.B., \& Lanouar, C. (2017). Renewable and Non-Renewable Energy Use Economic Growth Nexus: The Case of MENA Net Oil Importing Countries. Renewable and Sustainable Energy Reviews, 71, 127-140.

Li, Q., \& Reuveny, R. (2006). Democracy and Environmental Degradation. International Studies Quarterly, 50, 935-956.

Lv, Z. (2017). The Effect of Democracy on $\mathrm{CO}_{2}$ Emissions in Emerging Countries: Does the Level of Income Matter?' Renewable and Sustainable Energy Reviews, 72, 900-906.

Marques, A.C., \& Fuinhas, J.A. (2011). Drivers Promoting Renewable Energy: A Dynamic Panel Approach' Renewable and Sustainable Energy Reviews, 15, 1601-1608.

Massey, E., Biesbroek, R., Huitema, D., \& Jordan, A. (2014). Climate Policy Innovation: The Adoption and Diffusion of Adaptation Policies Across Europe.Global Environmental Change, 29, 434-443.

Midlarsky, M.I. (1998). Democracy and the Environment: An Empirical Assessment. Journal of Peace Research, 35, 341-361.

Neumayer, E. (2002). Do Democracies Exhibit Stronger International Environmental Commitment? A Cross-Country Analysis. Journal of Peace Research, 39, 139-164.

Pacesila, M., Burcea, S.G., \& Colesca, S.E. (2016). Analysis of Renewable Energies in European Union.' Renewable and Sustainable Energy Reviews, 56, 156-170.

Pfeiffer, B., \& Mulder, P. (2013). Explaining the Diffusion of Renewable Energy Technology in Developing Countries. Energy Economics, 40, 285-296.

Río, P.D., \& Mir-Artigues, P. (2014). Combinations of Support Instruments for Renewable Electricity in Europe: A Review. Renewable and Sustainable Energy Reviews, 40, 287-295.

Río, P.D., \& Tarancon, M-A. (2012). Analysing the determinants of on-shore wind capacity additions in the EU: an econometric study. Applied Energy, 95, 12-21.

Río, P.D., Resch, G., Ortner, A., Liebmann, L., Busch, S., \& Panzer, C. (2017). A Techno-Economic Analysis of EU Renewable Electricity Policy Pathways in 2030. Energy Policy, 104, 484-493.

Sahli, I., \& Rejeb, J.B. (2015). The Environmental Kuznets Curve and Corruption in the MENA Region. Procedia - Social and Behavioral Sciences, 195, 1648 - 1657.

Salim, R.A., \& Rafiq, S. (2012). Why do Some Emerging Economies Proactively Accelerate the Adoption of Renewable Energy? Energy Economics, 34, 1051-1057.

Schaffer, L.M., \& Bernauer, T. (2014). Explaining Government Choices for Promoting Renewable Energy. Energy Policy, 68, 15-27.

Stadelmann, M., \& Castro, P. (2014). Climate policy innovation in the South - Domestic and International Determinants of Renewable Energy Policies in Developing and Emerging Countries. Global Environmental Change, 29, 413-423.

Wang, Z., Danish, Zhang, B., \& Wang, B. (2018). The Moderating Role of Corruption Between Economic Growth and CO2 Emissions: Evidence from BRICS Economies. Energy, 148, 506513.

World Development Indicators. (2019). The World Bank Group. Retrieved from http://data.worldbank.org/indicator

World Governance Indicators. (2019). The World Bank Group. Retrieved from http://info.worldbank.org/governance/wgi/index.aspx\#home 


\section{APPENDIX}

TABLE A1

VARIABLES DEFINITIONS

\begin{tabular}{|l|l|}
\hline Variable & Definition \\
\hline Total Renewable Energy & Electricity Capacity, MW \\
\hline Renewable Energy consumption & (\% of total final energy consumption) \\
\hline Energy imports & Energy imports, net (\% of energy use) \\
\hline Energy use (per capita) & Energy use (kg of oil equivalent per capita) \\
\hline GDP per capita & GDP per capita (constant 2010 US\$) \\
\hline Total natural resources rents (\% of GDP) & $\begin{array}{l}\text { Total natural resources rents are the sum of oil rents, natural } \\
\text { gas rents, coal rents (hard and soft), mineral rents, and forest } \\
\text { rents. "Rents" are the difference between the value of } \\
\text { production at world prices and the total costs of production. }\end{array}$ \\
\hline Population & Total Population \\
\hline CO emissions from gas & CO ${ }_{2}$ emissions from gaseous fuel consumption (\% of total) \\
\hline CO ${ }_{2}$ emissions from liquid fuel & CO emissions from liquid fuel consumption (kt) \\
\hline Control of corruption (rank) & Control of Corruption: Percentile Rank \\
\hline Government effectiveness (rank) & Government Effectiveness: Percentile Rank \\
\hline Regulatory quality (rank) & Regulatory Quality: Percentile Rank \\
\hline Political stability (rank) & $\begin{array}{l}\text { Political Stability and Absence of Violence/Terrorism: } \\
\text { Percentile Rank }\end{array}$ \\
\hline Rule of law (rank) & Rule of Law: Percentile Rank \\
\hline Voice and accountability (rank) & Voice and Accountability: Percentile Rank \\
\hline European Union (EU) & EU=1 if country is EU member in a given year; 0 otherwise \\
\hline Western Europe (WEST) & WEST=1 if country belongs to WEST region; 0 otherwise \\
\hline Eastern Europe (EAST) & EAST=1 if country belongs to EAST region; 0 otherwise \\
\hline Former Soviet Union (FSU) & FSU=1 if country belongs to FSU region; 0 otherwise \\
\hline Middle East \& North Africa (MENA) & MENA=1 if country belongs to MENA region; 0 otherwise \\
\hline Source: The World Bank, World Developmen Indicators (2019) and IRENA (2019). \\
\hline
\end{tabular}


TABLE A2

DESCRIPTIVE STATISTICS

\begin{tabular}{|l|l|l|l|l|l|}
\hline Variable & N & Mean & Std. Dev. & Min & Max \\
\hline Total Renewable Energy & 1160 & 7065.06 & 13413.9 & 0 & 120014 \\
\hline Renewable Energy consumption & 1114 & 14.22074 & 15.77472 & 0 & 77.34468 \\
\hline Energy imports & 1072 & -21.16422 & 164.0121 & -843.4819 & 100 \\
\hline Energy use (per capita) & 1072 & 3483.781 & 3252.786 & 219.5899 & 21959.44 \\
\hline GDP per capita & 1183 & 21533.33 & 22502.62 & 365.4377 & 111968.4 \\
\hline Total natural resources rents (\% of GDP) & 1179 & 7.312149 & 13.18853 & 0 & 69.7266 \\
\hline Population (in 1000) & 1188 & 18497.71 & 26507.22 & 268.916 & 148160 \\
\hline $\mathrm{CO}_{2}$ emissions from gas & 1027 & 28.43618 & 22.61798 & 0 & 132.205 \\
\hline $\mathrm{CO}_{2}$ emissions from liquid fuel & 1027 & 49045.44 & 78290.5 & 366.7 & 424924.6 \\
\hline Control of corruption (rank) & 1185 & 58.22595 & 29.4232 & .5376344 & 100 \\
\hline Government effectiveness (rank) & 1175 & 62.01102 & 27.09872 & .5102041 & 100 \\
\hline Regulatory quality (rank) & 1174 & 62.71807 & 27.55683 & .5128205 & 100 \\
\hline Political stability (rank) & 1172 & 54.06116 & 28.8344 & 0 & 100 \\
\hline Rule of law (rank) & 1185 & 59.31703 & 29.23804 & .4784689 & 100 \\
\hline Voice and accountability (rank) & 1187 & 54.8112 & 32.17015 & 0 & 100 \\
\hline European Union (EU) & 1188 & .3872054 & .4873164 & 0 & 1 \\
\hline Western Europe (WEST) & 1188 & .2878788 & .452965 & 0 & 1 \\
\hline Eastern Europe (EAST) & 1188 & .2121212 & .4089824 & 0 & 1 \\
\hline Former Soviet Union (FSU) & 1188 & .2272727 & .4192467 & 0 & 1 \\
\hline Middle East \& North Africa (MENA) & 1188 & .2727273 & .4455493 & 0 & 1 \\
\hline Source: Th Word Bank, Wrd & &
\end{tabular}

Source: The World Bank, World Developmen Indicators (2019) and IRENA (2019). 